\title{
Comunicação
}

[Communication]

\section{Anticorpos para Borrelia burgdorferi em indivíduos que trabalham com animais silvestres}

[Antibodies specific to Borrelia burgdorferi in wild animal workers]

\author{
D.A. Corradi $^{1 *}$, V.M. Carvalho ${ }^{2}$, S.D. Coutinho ${ }^{2}$ \\ ${ }^{1}$ Médico Veterinário autônomo \\ ${ }^{2}$ Universidade Paulista - São Paulo, SP
}

A doença de Lyme caracteriza-se por ser uma enfermidade polissistêmica com alterações cutâneas, articulares, neurológicas e cardíacas, causada por Borrelia burgdorferi, que é transmitida pela picada de carrapatos da família Ixodidae, parasitas dos animais domésticos e silvestres (Joppert, 1995).

Embora a transmissão das borrelioses seja essencialmente por carrapatos do gênero Ixodes, pode ocorrer a transmissão por membros da família Argasidae e, em raros relatos, por culicídeos, tabanídeos e sifonapteros (Magnarelli et al., 1987). Sugere-se que, no Brasil, a espécie de carrapato potencialmente transmissora da doença de Lyme seja o Amblyoma cajennense (Yoshinari, 2001).

A doença de Lyme foi relatada em cervídeos, sendo esses animais considerados sentinelas epidemiológicas naturais da Borrelia burgdorferi (Steere et al., 1983). Carnívoros selvagens, lagoformos e marsupiais podem ser portadores de Borrelia $\mathrm{sp}$, sendo assim reservatórios naturais para esta doença (Benach et al.,1987). Roedores e aves silvestres merecem destaque, pois os primeiros transportam o patógeno do ambiente silvestre para o ambiente peridomiciliar (Barbour e Hayes, 1986), e as aves migratórias transportam os carrapatos infectados pela bactéria de uma região a outra (Olsen et al., 1995)

Recebido em 19 de novembro de 2004

Aceito em 19 de janeiro de 2006

*Endereço (mailing address): Rua Harmonia, 1054 - Vila

Madalena, CEP 05435-001 - São Paulo, SP

E-mail: corradi@hotmail.com

Apoio: UNIP
Estudos sorológicos em humanos (1067 amostras) realizados nas regiões de Itapevi e Cotia, estado de São Paulo, constataram 7,5\% de positivos no ELISA (Yoshinari, 2001). Em cães da cidade de Cotia, SP, Joppert (1995) relatou que $8,4 \%$ dos animais estudados apresentavam anticorpos da classe IgG para Borrelia burgdorferi. No Brasil também foram realizados estudos sorológicos em bovinos, que revelaram positividade acima de 50\% (Ishikawa et al., 1997).

Os resultados verificados nas populações humana e de animais domésticos no Brasil foram similares aos obtidos em áreas endêmicas dos Estados Unidos (Soares et al., 2000). Entretanto, não se tem conhecimento de pesquisas no Brasil que enfoquem os profissionais de risco, como indivíduos que trabalham diretamente com os animais silvestres, os quais são considerados reservatórios para Borrelia burgdorferi (Soares et al., 2000).

O objetivo deste trabalho foi realizar levantamento sorológico para a doença de Lyme, por ensaio imunoenzimático (ELISA) de pessoas que trabalham e têm contato estreito com animais silvestres, no município de São Paulo.

A população escolhida para o estudo foi composta de pessoas de ambos os sexos, idades variadas, e que, em seu trabalho diário, têm contato íntimo com animais silvestres ou matas nativas, preenchendo os requisitos epidemiológicos de um possível grupo de risco para a doença de Lyme. 
Os testes foram realizados em 78 soros de veterinários, biólogos e tratadores oriundos de duas instituições do município de São Paulo que foram selecionadas por albergarem animais silvestres, possibilitando proximidade e longo período de contato das pessoas com possíveis reservatórios da bactéria.

Foram coletados $10 \mathrm{ml}$ de sangue em tubos sem a adição de anticoagulantes. Durante a coleta, as pessoas preencheram uma ficha de identificação, com informações sobre: sexo, idade, grau de instrução, existência de carrapatos em contato com a pele, acometimento de sífilis, leptospirose ou outras doenças infecciosas.

No levantamento sorológico da doença de Lyme, utilizou-se o kit imunoenzimático (ELISA) ${ }^{1}$, para se detectar a presença de imunoglobulinas IgM e/ou IgG contra Borrelia burgdoferi. O teste detectou cinco amostras positivas $(6,4 \%)$, duas amostras suspeitas $(2,6 \%)$ e 71 amostras negativas $(91 \%)$.

Estima-se que a freqüência de soropositividade para a doença de Lyme na população brasileira seja de 3\%. Esse valor foi obtido por Yoshinari et al. (1997) que testaram os soros de pessoas saudáveis. No presente inquérito, obtiveram-se $6,4 \%$ de soropositividade nas pessoas que tiveram contato direto com animais silvestres. Embora existam variações nas porcentagens de soropositividade em pessoas sadias em outros países ( Stanchi e Balaque, 1993; Vazquez, 1997; Goossens et al., 2001), a porcentagem aqui verificada é maior que a estimada para a população brasileira como um todo e próxima àquela obtida na população da região de Cotia (7,5\%), que é considerada endêmica para a doença (Yoshinari et al., 1997).

As pesquisas realizadas sugerem a existência, no Brasil, de espécies de borrelias distintas das isoladas em outros países (Yoshinari et al., 1997; Abel et al., 2000; Costa et al., 2001). Os casos clínicos de borreliose têm sido esporádicos no Brasil (Yoshinari et al., 1997; Miguel et al., 1999; Costa et al., 2001) e, até o momento, o agente etiológico não foi isolado (Yoshinari, 2001). Esse fato implica que os testes sorológicos tenham de ser realizados com antígenos produzidos com espécies de espiroquetas isoladas em outras partes do mundo e sugere, portanto, que as porcentagens de positividade podem ser, na realidade, superiores às verificadas neste levantamento.

A população humana que foi testada neste trabalho mantém estreito contato com as espécies de animais silvestres citadas na literatura, como reservatório para Borrelia $\mathrm{sp}$, e com vetores considerados potencialmente transmissores da doença. Embora parte desses animais se encontre em cativeiro e sob cuidados veterinários há longo tempo, outra parte é proveniente de apreensão de tráfico, e seu contato com as matas é muito recente, estabelecendo uma interface de relação entre a natureza e os susceptíveis (homens e animais) nos recintos de manutenção.

Houve relação entre soropositividade e verificação prévia de possíveis vetores pelos indivíduos e entre soropositividade e tempo de trabalho com animais silvestres. A presença de carrapatos nas superfícies cutâneas é um forte indicador epidemiológico para um possível contato com o agente etiológico nos casos clínicos (Yoshinari et al., 1997; Soares et al., 2000; Costa et al., 2001). Dessa forma, revestese de importância o fato de $60 \%$ das pessoas soropositivas, neste levantamento, terem se referido a contato prévio com carrapatos. Verificou-se, também, que a maioria das pessoas trabalhava há 10-15 anos no ambiente, quase todas com idades acima de 40 anos. Portanto, aparentemente, quanto maior o tempo de trabalho com animais silvestres, maior o risco de infecção.

Não se detectou relação entre sexo, grau de instrução e histórico de outra doença infecciosa grave e soropositividade.

Em vista das condições epidemiológicas a que está exposta e da ocorrência de $6,4 \%$ de anticorpos para Borrelia burgdorferi, acredita-se que a população pesquisada possa ser considerada de risco para infecção pelo agente etiológico da doença de Lyme.

Palavras-chave: homem, Borrelia burgdorferi, animais silvestres, doença de Lyme

\footnotetext{
${ }^{1}$ Sigma Diagnostics - USA
} 


\begin{abstract}
The occurrence of serum antibodies to Borrelia burgdorferi in professionals in close contact with wild animals was determined. Seventy eight technicians workers coming from two São Paulo public institutions housing wild animals had their blood collected (serum samples). All samples were submitted to ELISA for IgM and $\operatorname{IgG}$ antibodies against Borrelia burgdorferi. The results showed five positive (6.4\%), two suspect (2.6\%) and 71 negatives (91\%) samples. Based on positive results it is concluded that the infection level is higher to that detected in the general population and similar to values of endemic areas, concluding that this assessed population could be considered at risk for Lyme disease.
\end{abstract}

Keywords: Borrelia burgdorferi, wild animals, Lyme disease, wild animal workers

\section{REFERÊNCIAS BIBLIOGRAFICAS}

ABEL I.S.; MARZAGÃO G.; YOSHINARI N.H. et al. Borrelia-like spirochetes recovered from ticks and small mammals collected in the Atlantic Forest Reserv, Cotia County, State of São Paulo, Brazil. Mem. Inst. Oswaldo Cruz, v.95, 2000. Disponível em $<$ http://www.scielo.com.br $>$. Acessado em $15 / 06 / 2002$.

BARBOUR, A.G.; HAYES S.F. Biology of Borrelia species. Microbiol. Rev., v.50, p.381-400, 1986.

BENACH J.L.; COLEMAN J.H.; SKINNER R.A. et al. Adult Ixodes dammini on rabbits: a hypothesis for the development and transmission of Borrelia burgdorferi. J. Infec. Dis, v.155, p.1300-1306, 1987.

COSTA, I.P.; BONOLDI, V.L.N.; YOSHINARI, N.H. Perfil clínico e laboratorial da doença de Lyme-simile no estado do Mato Grosso do Sul: análise de 16 pacientes. Rev. Bras. Reumatol., v.41, p.142-149, 2001.

GOOSSENS H.A.; VAN DEN BOGAARD A.E.; NOHLMANS M.K. Dogs as sentinels for human lyme borreliosis in the Nertherlands. J. Clin. Microbiol., v.39, p.844-848, 2001.

ISHIKAWA, M.M.; FONSECA, A.H.; SOARES, C.O. et al. Padronização de ensaio imunoenzimático ELISA indireto para pesquisa de anticorpos IgG contra Borrelia burgdorferi em bovinos. Rev. Bras. Med. Vet., v.19, p.166-168, 1997.

JOPPERT, A.M. Estudo soroepidemiológico da infecção por Borrelia burgdorferi em cães da região de Cotia, São Paulo. 1995. 84f. Tese (Mestrado em Medicina Veterinária) - Faculdade de Medicina Veterinária e Zootecnia, Universidade de São Paulo, São Paulo.

MAGNARELLI, L.A.; ANDERSON, J.F.; SCHREIER, A.B. et al. Clinical and serologic studies of canine borreliosis. J. Am. Vet. Med. Assoc., v.191, p.1089-1094, 1987.

MIGUEL, E.R.A.; CUNHA, I.P.P.; AZEVEDO, C.E.S. Doença de Lyme. In: SCHETTINO, C. E. Doenças exantemáticas em pediatria e outras doenças cutâneas. 3.ed. São Paulo: Atheneu, 1999, p. 103-106.

OLSEN, B.; DUFFY, D. C.; JAENSON, T. G. T. et al. Transhemispheric exchange of Lyme disease spirochetes by seabirds. J. Clin. Microbiol., v.33, p.3270-3274, 1995.

SOARES, C. O.; ISHIKAWA, M. M.; FONSECA, A. H. et al. Borrelioses, agentes e vetores. Pesq. Vet. Bras., v.20, 2000. Disponível em: $<$ http://www.scielosp.org>. Acessado em: 15/05/2001.

STANCHI N.O.; BALAGUE L.J. Lyme disease: antibodies against Borrelia burgdorferi in farm workers in Argentina. Rev. Saúde Publ., v.27, p.305307, 1993.

STEERE. A.C.; GRODZICKI, R.L.; KORNBLATT A.N. The spirochetal etiology of Lyme disease. $N$. Engl. J. Med., v.308, p.733 - 740, 1983.

VÁZQUEZ J. R. Seroprevalencia de la infección por Borrelia burgdorferi y Rickettsia conorii en población humana y canina de la zona básica de salud de San Andrés del Rabanedo (León, España). Rev. Esp. Salud Publ., v.71, p.173-180, 1997. Disponível em $<$ http://www.scielosp.org>. Acessado em: 08/07/2005.

YOSHINARI, N. H.; BARROS P. J. L.; BONOLDI, V.L.N. et al. Perfil da borreliose de Lyme no Brasil. Rev. Hosp. Clín. Fac. Med. S. Paulo, v.52, p.111-117, 1997.

YOSHINARI, N.H. Doença de Lyme-simile no Brasil. Rev. Assoc. Nac. Clin. Vet. Peq. Anim., v.26, p.13, 2001. 